\title{
Synthesis and Biological Evaluation of New CRH Analogues
}

\author{
Spyridon Papazacharias, ${ }^{1}$ Vassiliki Magafa, ${ }^{1}$ Nicole Bernad, ${ }^{2}$ George Pairas, ${ }^{1}$ \\ Georgios A. Spyroulias, ${ }^{1}$ Jean Martinez, ${ }^{2}$ and Paul Cordopatis ${ }^{1}$ \\ ${ }^{1}$ Laboratory of Pharmacognosy and Chemistry of Natural Products, Department of Pharmacy, University of Patras, \\ 26500 Patras, Greece \\ ${ }^{2}$ Institut des Biomolécules Max Mousseron (IBMM), UMR-CNRS, Faculté de Pharmacie, Universités Montpellier 1 et 2, \\ 15 Av. C. Flahault, 34093 Montpellier, France
}

Correspondence should be addressed to Vassiliki Magafa, magafa@upatras.gr

Received 24 February 2010; Accepted 20 April 2010

Academic Editor: Spyros Perlepes

Copyright () 2010 Spyridon Papazacharias et al. This is an open access article distributed under the Creative Commons Attribution License, which permits unrestricted use, distribution, and reproduction in any medium, provided the original work is properly cited.

\begin{abstract}
A series of 7 new human/rat Corticotropin Releasing Hormone (h/r-CRH) analogues were synthesized. The induced alterations include substitution of Phe at position 12 with D-Phe, Leu at positions 14 and 15 with Aib and Met at positions 21 and 38 with $\mathrm{Cys}(\mathrm{Et})$ and $\mathrm{Cys}(\mathrm{Pr})$. The analogues were tested regarding their binding affinity to the $\mathrm{CRH}-1$ receptor and their activity which is represented by means of percentage of maximum response in comparison to the native molecule. The results indicated that the introduction of Aib, or Cys derivatives although altering the secondary structure of the molecule, did not hinder receptor recognition and binding.
\end{abstract}

\section{Introduction}

Ever since its identification by Vale et al. [1], Corticotropin Releasing Hormone (CRH) has proven to be a major neuromodulator responsible not only for the secretion of ACTH by the anterior pituitary gland but also for the regulation of the endocrine, autonomic, immunological and behavioral responses to stress [2-4]. Furthermore, this 41amino acid neuropeptide displays a plethora of additional roles in either physiological homeostasis or pathogenic manifestations varying from the well-established implication on neuropsychiatric disorders $[5,6]$ to the yet to be clarified actions on various forms of cardiovascular diseases [7] obesity [8] or gut motility [9], among others. A series of studies demonstrating the extent and perplexity of the roles and implications of $\mathrm{CRH}$ led to the identification of other peptides appearing to possess a similar role [10-13].

Both the isolation and characterization of the $\mathrm{CRH}$ family receptors has been achieved revealing two receptor subtypes, one of them appearing as three splice variants $\left(\mathrm{CRH}-\mathrm{R} 1, \mathrm{CRH}-\mathrm{R} 2_{\alpha}, \mathrm{CRH}-\mathrm{R} 2_{\beta}\right.$, and $\left.\mathrm{CRH}-\mathrm{R} 2_{\gamma}\right)$. A binding protein (CRH-BP) was also described [14-18].The moststudied receptor types are CRH-R1, CRH-R2 $2_{\alpha}$, and $\mathrm{CRH}-$ $\mathrm{R} 2 \beta$ not only due to their vast distribution but also for their implication in physiological functions or disorders of great importance. CRH-R1 is broadly distributed in the brain and the pituitary gland but also appears in a number of peripheral tissues [19]. It possesses a critical role in mediating the hypophysiotropic action of $\mathrm{CRH}$ [20] but furthermore is involved in anxiogenic behaviours, depression and anxiety [21], anorexia and bulimia, drug seeking and withdrawal, and seizure $[22,23]$. CRH-R $2_{\alpha}$ is mainly a brain receptor whereas $\mathrm{CRH}-\mathrm{R} 2_{\beta}$ is largely expressed in the periphery. The role of $\mathrm{CRH}-\mathrm{R} 2$ is more diverse since it extends from "stress-coping" responses (anxiolysis, hypotension) to gastric emptying, regulation of energy expenditure, anti-inflammatory, and other actions of CRH [24]. However, further and complete understanding of the hormone-receptor interaction on its chemical basis is essential mainly since it can provide a solid basis for the development of $\mathrm{CRH}$ analogues with potent therapeutical implications. 
Two distinct categories of CRH receptor ligands (of either agonistic or antagonistic character) have been developed, namely, peptide and nonpeptide ligands. The latter are unambiguously a large and diverse family but only few of these small molecules entered clinical development and still none of them found its way to the market [25]. The former category is more likely to yield clear information regarding the interaction between the peptide and its receptor.

Towards this goal, extensive SAR studies have been carried out. Single amino acid modification studies identified the key regions of the peptide for agonist/antagonist properties as well as for the receptor binding affinity. Based on these studies, the assignment of the molecule's secondary structure was feasible leading to the establishment of an $\alpha$-helical structure (showing high amphiphilicity) for CRH-related peptides as the preferred conformation [9]. Notably, the helical nature of the molecule varies from $20 \%$ in solution to $80 \%$ upon binding [26].

A hypothesis was that stabilization of the $\alpha$-helix could affect positively the activity of either agonists or antagonists. Subsequent studies affirmed this conjecture establishing that conformationally restrained analogues present increased potency. In addition, modifications on hydrophilicity/hydrophobicity or acidity/basicity of some residues were crucial in altering the potency of an analogue [26].

Introduction of D-amino acids leading to stabilization of $\beta$-turns, can provide analogues with increased potency but not all residues are susceptible to such an alteration, leading even to the opposite effect. However, the D-Phe ${ }^{12}$ substitution has proven to be a favorable one especially combined with other advantageous modifications such as the replacement of Met at positions 21 and 38 with Nle. Thus, it has been shown that $\left[\mathrm{D}-\mathrm{Phe}^{12}\right] \mathrm{CRH}$ is twice as potent and $\left[\mathrm{D}-\mathrm{Phe}^{12}, \mathrm{Nle}^{21,38}\right] \mathrm{CRH}_{21-41}$ is 15 times more potent than $\alpha$ helical CRH [26].

The present study presents the synthesis of 7 new $\mathrm{h} / \mathrm{r}$ $\mathrm{CRH}$ analogues bearing minor modifications on the key amino acids side chain, regarding their electrochemical nature (Table 1). Specifically, we discuss the replacement of Leu at positions 14 and 15 with $\alpha$-Aminoisobutyric acid (Aib), which apart from introducing a bend in the peptide backbone can stabilize the $a$-helix structure $[27,28]$, and also the replacement of Met at positions 21 and 38. The amino acids used for the latter modification are Cysteine(Ethyl) $[\mathrm{Cys}(\mathrm{Et})]$, an isoster of Met and Cysteine(Propyl) [Cys(Pr)] that possesses a slightly more hydrophobic side chain than $\mathrm{Cys}(\mathrm{Et})$. The analogues were tested regarding their ability to induce the formation of intracellular cAMP in comparison to natural CRH measured by means of luciferase activity.

\section{Experimental}

2.1. Materials. 2-chlorotrityl-chloride resin bearing a Rink-Bernatowitz linker and 9-Fluorenylmethoxycarbonyl (Fmoc)-protected amino acids were supplied by CBL Patras. All solvents and reagents used for solid-phase peptide synthesis were purchased from Bachem AG and
Novabiochem and were used without further purification being of analytical quality. Nonnatural amino acid derivatives Cysteine (Ethyl) [Cys(Et)] and Cysteine (Propyl) $[\mathrm{Cys}(\mathrm{Pr})]$ were prepared according to literature [29].

2.2. Peptide Synthesis and Purification. Synthesis of the analogues was performed via Fmoc solid phase methodology [30] utilizing either Rink Amide MBHA resin [31] or 2chlorotrityl-chloride resin [32] bearing a Rink-Bernatowitz linker [33] to provide the peptide amide. The side-chain protection used for the Fmoc-protected amino acids was the trityl group (Trt) for His, Asn, and Gln, the tert-butyl group $\left(\mathrm{Bu}^{t}\right)$ for Asp, Tyr, Glu, Ser and Thr, the tertbutyloxy-carbonyl group (Boc) for Lys and the 2,2,4,6,7pentamethyl-dihydrobenzofuran-5-sulphonyl group ( $\mathrm{Pbf}$ ) for Arg. Stepwise synthesis of the peptide analogues was preferred to convergent synthesis due to the lack of Gly or Pro moieties at convenient positions in the amino acid sequence. The amino acids were coupled at three-fold excess using diisopropylcarbodiimide/1-hydroxybenzotriazole (DIC/HOBt) $[34,35]$ in Dimethylformamide (DMF) and, if necessary, 2-(1H-benzotriazole-1-yil)-1,1,3,3-tetramethyluroniumhexafluorophosphate (TBTU)/HOBt/diisopropyl ethylamine (DIEA) in DMF [36]. After 2 hours coupling time at room temperature, the ninhydrin test [37] was performed to estimate the completeness of the reaction with the exception of coupling on a Pro residue where the Chloranil test was employed to confirm reaction's completion point [38]. Fmoc groups were removed by treatment with $20 \%$ piperidine in DMF for 5 minutes followed by a prolonged treatment with the same solution for 20 minutes to ensure complete removal. The final cleavage of the peptide from the solid support together with the removal of the side-chain protecting groups was accomplished by treatment with a solution $(15 \mathrm{~mL} / \mathrm{g}$ peptide resin) of trifluoroacetic acid (TFA)/1,2ethanedithiol/anisole/triethylsilane/water $(94: 2.5: 0.5: 1.5$ : $1.5, \mathrm{v} / \mathrm{v}$ ) for 4 hours at room temperature. The obtained mixture underwent solvent evaporation followed by anhydrous ethyl ether precipitation to yield the final crude peptide.

All the products were purified by gel filtration chromatography on Sephadex G-25 (fine) using 25\% acetic acid as eluent. Final purification was achieved by preparative high performance liquid chromatography (HPLC, Pharmacia LKB-2250) on reversed-phase support C-18 with a linear gradient from 30 to $85 \%$ acetonitrile $(0.1 \%$ TFA) for 35 minutes at a flow rate $1.5 \mathrm{~mL} / \mathrm{min}$ and UV detection at 230 and $254 \mathrm{~nm}$. The appropriate fractions were pooled and lyophilized. Analytical HPLC (Pharmacia LKB-2210) equipped with a Nucleosil $100 \mathrm{C}_{18}$ column $(5 \mu \mathrm{m}$ particle size; $250 \times 4.6 \mathrm{~mm}$ ) produced single peaks with at least $98 \%$ of the total peptide peak integrals. The solvent system used was the same as that for the semipreparative HPLC. All products gave single spots on thin layer chromatography (TLC, Merck precoated silica gel plates, type $\left.\mathrm{G}_{60}-\mathrm{F}_{254}\right)$ in the solvent systems: (A) 1-butanol: acetic acid: water (4:1:5, upper phase) and (B) 1-butanol: acetic acid: water: pyridine (15:3:10:6). The final characterization of the peptide sequence was 
TABLE 1: Structure of synthesized CRH analogues.

\begin{tabular}{|c|c|c|c|c|c|c|c|c|}
\hline & Human/Rat CRH & Analogue 1 & Analogue 2 & Analogue 3 & Analogue 4 & Analogue 5 & Analogue 6 & Analogue 7 \\
\hline 1 & S & & & & & & & \\
\hline 2 & E & & & & & & & \\
\hline 3 & E & & & & & & & \\
\hline 4 & $\mathrm{P}$ & & & & & & & \\
\hline 5 & $\mathrm{P}$ & & & & & & & \\
\hline 6 & I & & & & & & & \\
\hline 7 & S & & & & & & & \\
\hline 8 & $\mathrm{~L}$ & & & & & & & \\
\hline 9 & D & & & & & & & \\
\hline 10 & $\mathrm{~L}$ & & & & & & & \\
\hline 11 & $\mathrm{~T}$ & & & & & & & \\
\hline 12 & $\underline{E}$ & D-phe & D-phe & D-phe & D-phe & D-phe & D-phe & D-phe \\
\hline 13 & $\mathrm{H}$ & & & & & & & \\
\hline 14 & $\underline{\mathrm{L}}$ & Aib & & & & & & \\
\hline 15 & $\underline{\mathrm{L}}$ & & Aib & & & & & \\
\hline 16 & $\mathrm{R}$ & & & & & & & \\
\hline 17 & $\mathrm{E}$ & & & & & & & \\
\hline 18 & V & & & & & & & \\
\hline 19 & $\mathrm{~L}$ & & & & & & & \\
\hline 20 & E & & & & & & & \\
\hline 21 & $\underline{\mathrm{M}}$ & & & Cys(Et) & & Cys(Et) & Cys $(\operatorname{Pr})$ & Cys $(\operatorname{Pr})$ \\
\hline 22 & $\bar{A}$ & & & & & & & \\
\hline 23 & $\mathrm{R}$ & & & & & & & \\
\hline 24 & A & & & & & & & \\
\hline 25 & $\mathrm{E}$ & & & & & & & \\
\hline 26 & Q & & & & & & & \\
\hline 27 & L & & & & & & & \\
\hline 28 & A & & & & & & & \\
\hline 29 & Q & & & & & & & \\
\hline 30 & $\mathrm{Q}$ & & & & & & & \\
\hline 31 & A & & & & & & & \\
\hline 32 & $\mathrm{H}$ & & & & & & & \\
\hline 33 & s & & & & & & & \\
\hline 34 & $\mathrm{~N}$ & & & & & & & \\
\hline 35 & $\mathrm{R}$ & & & & & & & \\
\hline 36 & K & & & & & & & \\
\hline 37 & $\mathrm{~L}$ & & & & & & & \\
\hline 38 & $\underline{\mathrm{M}}$ & & & & Cys $(\operatorname{Pr})$ & Cys $(\operatorname{Pr})$ & Cys(Et) & Cys $(\operatorname{Pr})$ \\
\hline 39 & E & & & & & & & \\
\hline 40 & I & & & & & & & \\
\hline 41 & I & & & & & & & \\
\hline
\end{tabular}

achieved by Electrospray Ionisation-Mass Spectrometry (ESI-MS, Micromass-Platform LC instrument). An example of analytical HPLC-chromatograms and ESI-MS spectrum are shown in Figure 1 for analogue 7. The physiochemical properties of the new analogues are summarized in Table 2.

2.3. Biological Assays. The capacity of $\mathrm{CRH}$ and related peptide analogues to stimulate cyclic AMP generation was monitored in LLC-PK1 cells cotransfected with cDNA of
CRH-R1 and CRE. For transfection the method of electroporation was applied and 40 millions of LLC-PK1 cells were prepared and washed in cytomix $1 \mathrm{X}$ transfection medium. The electroporation medium consisted of $1000 \mu \mathrm{L}$ of cytomix $2 \mathrm{X}, 864 \mu \mathrm{L}$ of sterilized water, $80 \mu \mathrm{L}$ of ATP $50 \mathrm{mM}, 3.2 \mathrm{mg}$ of glutathion, $20 \mu \mathrm{g}$ of CRH-R $1 \mathrm{cDNA}$ and $20 \mu \mathrm{g}$ of CRE cDNA. $500 \mu \mathrm{L}$ of the above solution were transferred in the electroporation device and after remaining for 10 minutes a standard growth medium was added (DMEM without 


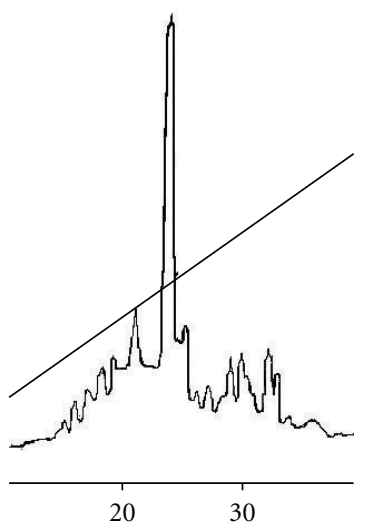

(a)

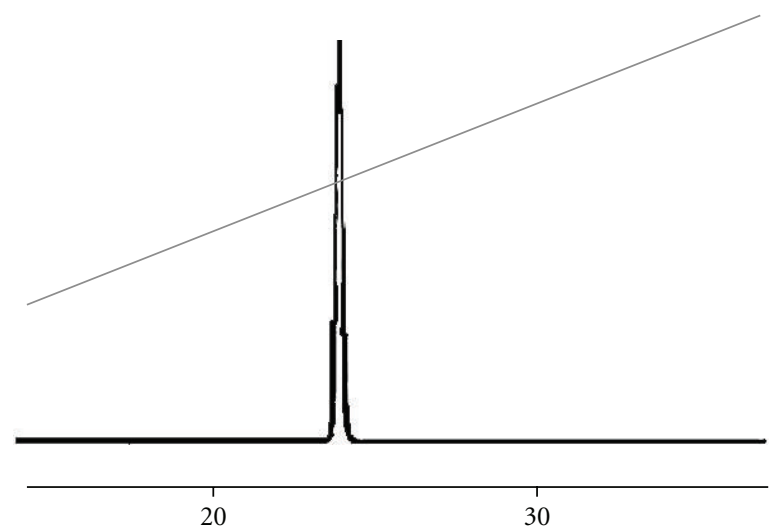

(b)

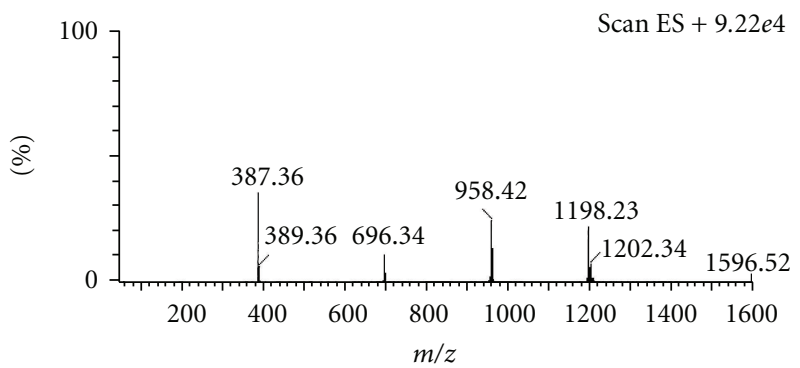

(c)

Figure 1: (a) Analytical HPLC chromatogram of crude analogue $\left[\mathrm{D}-\mathrm{Ph} \mathrm{e}^{12}, \mathrm{Cys}(\mathrm{Pr})^{21}, \mathrm{Cys}(\mathrm{Pr})^{38}\right] \mathrm{CRH}$ previously chromatographed on a semipreparative C18 column. (b) Analytical HPLC chromatogram of analogue $\left[\mathrm{D}-\mathrm{Ph} \mathrm{e}^{12}\right.$, Cys $(\mathrm{Pr})^{21}$, Cys $(\mathrm{Pr})^{38}$ ]CRH upon rechromatography on the same column. (c) Mass spectra of analogue $\left[\mathrm{D}-\mathrm{Phe} \mathrm{e}^{12}, \mathrm{Cys}(\mathrm{Pr})^{21}, \mathrm{Cys}(\mathrm{Pr})^{38}\right] \mathrm{CRH}$ resulting from ESI-MS analysis $[\mathrm{MW}$ calc $=4785.58$; $\left.(\mathrm{M}+4)_{\mathrm{obs}}{ }^{4+} / 4=1198.2 ;(\mathrm{M}+3)_{\mathrm{obs}}^{3+} / 3=1596.5\right]$.

TABLE 2: Physicochemical properties of $\mathrm{h} / \mathrm{r}-\mathrm{CRH}$ analogues used in the present study.

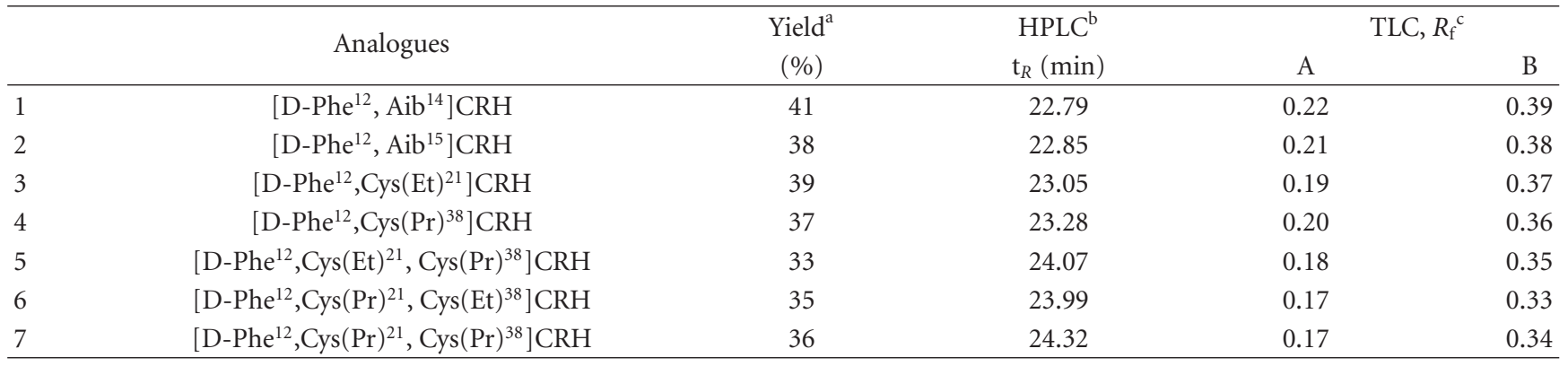

${ }^{a}$ Yields were calculated on the basis of the amino acid content of the resin. All peptides were at least $98 \%$ pure.

${ }^{\mathrm{b}}$ For elution conditions, see the Experimental Section.

${ }^{\mathrm{c}}$ Solvent systems and conditions are reported in the Experimental Section.

phenol red with glutamine, antibiotics, and 10\% FCS) to a total volume of $50 \mathrm{~mL}$. The suspension was distributed in 8 plates of 24 wells each, by adding $1 \mathrm{~mL}$ per well, and was allowed to pre-incubate for 24 hours. The growth medium was aspirated and replaced with fresh one followed by another preincubation for 24 hours. The cells were then challenged with graded concentrations $\left(10^{-6}\right.$ to $\left.10^{-11} \mathrm{M}\right)$ of the test peptides and incubated for 7 hours at $37^{\circ} \mathrm{C}$. After that, the medium with the added peptides was removed, the cells were washed twice with PBS $1 \mathrm{X}, 100 \mu \mathrm{L}$ of lysis buffer 1X per well were added, the plates were left at room temperature for 30 minutes and then stored at $-80^{\circ} \mathrm{C}$ overnight. The luciferace activity was measured with the use of a luminometer after the addition of $50 \mu \mathrm{L}$ of lysed cell preparation and $50 \mu \mathrm{L}$ of bioluminescence medium per well in a 96 well plate luminometer.

\section{Results}

3.1. Peptide Synthesis and Purification. All analogues shown in Table 2 were synthesized either manually or automatically 
TABLE 3: Binding affinities of $\mathrm{h} / \mathrm{r}-\mathrm{CRH}$ analogues.

\begin{tabular}{|c|c|c|}
\hline & Analogues & Binding affinity ${ }^{\mathrm{a}} \mathrm{IC}_{50}(\mathrm{nM})$ \\
\hline & $\mathrm{h} / \mathrm{r}-\mathrm{CRH}$ & 17.3 \\
\hline 1 & {$\left[\mathrm{D}-\mathrm{Phe}^{12}, \mathrm{Aib}^{14}\right] \mathrm{CRH}$} & 226 \\
\hline 2 & {$\left[\mathrm{D}-\mathrm{Phe}^{12}, \mathrm{Aib}^{15}\right] \mathrm{CRH}$} & 8.4 \\
\hline 3 & {$\left[\mathrm{D}-\mathrm{Phe}^{12}, \mathrm{Cys}(\mathrm{Et})^{21}\right] \mathrm{CRH}$} & 28.5 \\
\hline 4 & {$\left[\mathrm{D}-\mathrm{Ph} \mathrm{e}^{12}, \mathrm{Cys}(\mathrm{Pr})^{38}\right] \mathrm{CRH}$} & 35 \\
\hline 5 & {$\left[\mathrm{D}-\mathrm{Phe}{ }^{12}, \mathrm{Cys}(\mathrm{Et})^{21}, \mathrm{Cys}(\mathrm{Pr})^{38}\right] \mathrm{CRH}$} & 7.0 \\
\hline 6 & {$\left[\mathrm{D}-\mathrm{Phe} \mathrm{e}^{12}, \mathrm{Cys}(\mathrm{Pr})^{21}, \mathrm{Cys}(\mathrm{Et})^{38}\right] \mathrm{CRH}$} & 3.4 \\
\hline 7 & {$\left[\mathrm{D}-\mathrm{Phe}^{12}, \mathrm{Cys}(\mathrm{Pr})^{21}, \mathrm{Cys}(\mathrm{Pr})^{38}\right] \mathrm{CRH}$} & 17.3 \\
\hline
\end{tabular}

${ }^{\mathrm{a}}$ The values given are averages from 3 experiments performed in duplicates.

TABLE 4: Biological activity of h/r-CRH analogues.

\begin{tabular}{|c|c|c|}
\hline & Analogues & Biological activity \\
\hline & $\mathrm{h} / \mathrm{r}-\mathrm{CRH}$ & $100 \%$ activity (Full agonist) \\
\hline 1 & {$\left[\mathrm{D}-\mathrm{Phe}^{12}, \mathrm{Aib}^{14}\right] \mathrm{CRH}$} & (Partial Agonist, 60\% Response max/CRH) \\
\hline 2 & {$\left[\mathrm{D}-\mathrm{Phe}^{12}, \mathrm{Aib}^{15}\right] \mathrm{CRH}$} & (Partial Agonist, 60\% Response max/CRH) \\
\hline 3 & {$\left[\mathrm{D}-\mathrm{Phe}^{12}, \mathrm{Cys}(\mathrm{Et})^{21}\right] \mathrm{CRH}$} & (Full Agonist, 110\% Response max/CRH) \\
\hline 4 & {$\left[\mathrm{D}-\mathrm{Ph} \mathrm{e}^{12}, \mathrm{Cys}(\mathrm{Pr})^{38}\right] \mathrm{CRH}$} & (Partial Agonist, $60 \%$ Response max/CRH) \\
\hline 5 & {$\left[\mathrm{D}-\mathrm{Phe}{ }^{12}, \mathrm{Cys}(\mathrm{Et})^{21}, \mathrm{Cys}(\mathrm{Pr})^{38}\right] \mathrm{CRH}$} & (Partial Agonist, 70\% Response max/CRH) \\
\hline 6 & {$\left[\mathrm{D}-\mathrm{Phe}{ }^{12}, \mathrm{Cys}(\mathrm{Pr})^{21}, \mathrm{Cys}(\mathrm{Et})^{38}\right] \mathrm{CRH}$} & (Partial Agonist, $60 \%$ Response max/CRH) \\
\hline 7 & {$\left[\mathrm{D}-\mathrm{Phe}^{12}, \mathrm{Cys}(\operatorname{Pr})^{21}, \mathrm{Cys}(\operatorname{Pr})^{38}\right] \mathrm{CRH}$} & (Partial Agonist, $80 \%$ Response max/CRH) \\
\hline
\end{tabular}

on the Rink Amide MBHA resin or the 2-chlorotritylchloride resin bearing a Rink-Bernatowitz linker as solid support by using standard coupling procedures and Fmoc/Bu ${ }^{t}$ strategy. The overall yield of the syntheses of the $\mathrm{CRH}$ analogues was in the range $33-41 \%$ (calculated on the amount of linker initially coupled to the resin). Higher yields were obtained using the Rink Amide MBHA as solid support.

The synthetic procedure did not present significant complications due to the highly helical nature of the analogues despite the considerable size of the CRH analogues. ESI mass spectrometry confirmed that the purified products were indeed the desired peptides and analytical HPLC revealed a purity of over than $98 \%$ for the synthetic analogues.

3.2. Biological Activity. The results of the biological evaluation regarding the synthesized analogues are set out in Tables 3 and 4 . The $\mathrm{IC}_{50}$ values (Table 3 ) indicate a not very wide but nonetheless notable variety in the affinity to the receptor for the studied analogues. Specifically, three of the analogues, namely, [D-Phe $\left.{ }^{12}, \mathrm{Aib}^{15}\right] \mathrm{CRH},\left[\mathrm{D}-\mathrm{Phe}^{12}, \mathrm{Cys}(\mathrm{Et})^{21}\right.$, $\left.\mathrm{Cys}(\operatorname{Pr})^{38}\right] \mathrm{CRH}$, and $\left[\mathrm{D}-\mathrm{Phe}{ }^{12}, \mathrm{Cys}(\mathrm{Pr})^{21}, \mathrm{Cys}(\mathrm{Et})^{38}\right] \mathrm{CRH}$, present a higher affinity to the receptor $\left(\mathrm{IC}_{50}=8.4 \mathrm{nM}\right.$, $\mathrm{IC}_{50}=7.0 \mathrm{nM}$ and $\mathrm{IC}_{50}=3.4 \mathrm{nM}$, resp.) which is approximately $2,2,5$, and 5 times that of the natural $\mathrm{h} / \mathrm{r}-\mathrm{CRH}\left(\mathrm{IC}_{50}=17.3\right.$ $\mathrm{nM})$. [D-Phe $\left.{ }^{12}, \mathrm{Aib}^{14}\right] \mathrm{CRH}$ is the analogue that presents the higher $\mathrm{IC}_{50}$ value $(226 \mathrm{nM})$ indicating a smaller affinity to the receptor, roughly 13 times lower than that of the hormone. The other three analogues appear to have the same ([D$\left.\left.\mathrm{Phe}^{12}, \mathrm{Cys}(\operatorname{Pr})^{21}, \mathrm{Cys}(\mathrm{Pr})^{38}\right] \mathrm{CRH}, \mathrm{IC}_{50}=17.3 \mathrm{nM}\right)$ or slightly reduced $\left(\left[\mathrm{D}-\mathrm{Phe} \mathrm{i}^{12}, \mathrm{Cys}(\mathrm{Et})^{21}\right] \mathrm{CRH}, \mathrm{IC}_{50}=28.5 \mathrm{nM}\right.$ and $[\mathrm{D}$ $\left.\left.\mathrm{Phe}^{12}, \mathrm{Cys}(\mathrm{Pr})^{38}\right] \mathrm{CRH}, \mathrm{IC}_{50}=35.0 \mathrm{nM}\right)$ affinity compared to $\mathrm{CRH}$.

Regarding the activity of the analogues which is represented by means of percentage of maximum response compared to that of $\mathrm{h} / \mathrm{r}-\mathrm{CRH}$ (Table 4 ), the only analogue that presents a higher percentage is $\left[\mathrm{D}-\mathrm{Ph} e^{12}, \mathrm{Cys}(\mathrm{Et})^{21}\right] \mathrm{CRH}$ (full agonist, $110 \%$ response max/CRH). All other analogues are partial agonists and induce a maximum response that varies between 60 and 80 per cent of the maximum response induced by CRH.

\section{Discussion}

The design and synthesis of the seven analogues was based on observations and results already mentioned above and likely to yield products with desirable properties. D-Phe ${ }^{12}$ substitution was a modification present in all analogues since it brings only a positive contribution to the potency and the activity of the analogue. Substitution of Leu at positions 14 and 15 with Aib was based on studies demonstrating that $\alpha$-aminoisobutyric acid is a helix-promoter/stabilizer, which increases the helix propensity of a peptide fragment towards, either $\alpha$ - or $3_{10}$ - helix, by restriction of the backbone conformational freedom. Aib, on the other hand, apart from its tendency to form constrained helices, is also known for its ability to bend helical peptides. The conformational features of the analogue [D-Phe $\left.{ }^{12}, \mathrm{Aib}^{15}\right] \mathrm{CRH}$ have already been studied through $1 \mathrm{D}$ and $2 \mathrm{D} J$-correlated ${ }^{1} \mathrm{HNMR}$ spectroscopy [39]. 
Biological evaluation of the two Aib containing analogues revealed that they both present the same activity which is 60 percent that of the natural hormone and thus, they appear to be partial agonists of CRH. However, when the $\mathrm{IC}_{50}$ values are taken under consideration, the two analogues significantly vary regarding their affinity to the receptor. Although the only difference in their secondary structure is the position of the Aib moiety (14 or 15) and furthermore, the two positions are adjacent, [D-Phe ${ }^{12}$, Aib $^{15}$ ]CRH presents a roughly 27 times higher affinity than $\left[\mathrm{D}-\mathrm{Phe}^{12}, \mathrm{Aib}^{14}\right] \mathrm{CRH}$. An NMR study of [D-Phe ${ }^{12}$, $\mathrm{Aib}^{14} \mathrm{CRH}$ and consequent comparison with the results already extrapolated for $\left[\mathrm{D}-\mathrm{Phe}^{12}, \mathrm{Aib}^{15}\right] \mathrm{CRH}$ is the best means to clarify the effect of the Aib substitution on the molecule conformation and consequently on its binding to the receptor. All the same, a primary estimation could be that the positions 14 and 15 although important for binding to the receptor might not belong to the region that is responsible for the hormone's action since no alteration is observed on the biological activity for the two analogues.

Cys(Et) and $\mathrm{Cys}(\mathrm{Pr})$ are two nonnatural amino acid residues that have already been used in the synthesis of peptides (e.g., Angiotensin II) [40] yielding interesting results. The fact that Cys (S-Et) is an isoster of Met along with the enhanced potency of the analogues with substituted $\mathrm{Met}^{21}$ or $\mathrm{Met}^{38}$ were basically taken into account for the design of the analogues. Cys (S-Pr) was used since it bears a side-chain that on one hand possesses the $\mathrm{S}$ atom present in Met and on the other hand has a longer aliphatic unit than Met or Cys(Et). Two of the analogues were monosubstituted regarding the Met residues, $\left[\mathrm{D}-\mathrm{Phe}{ }^{12}, \mathrm{Cys}(\mathrm{Et})^{21}\right] \mathrm{CRH}$, and $\left[\mathrm{D}-\mathrm{Phe}^{12}, \mathrm{Cys}(\mathrm{Pr})^{38}\right] \mathrm{CRH}$, and three had a double substitution of Met, [D-Phe $\left.{ }^{12}, \mathrm{Cys}(\mathrm{Et})^{21}, \mathrm{Cys}(\mathrm{Pr})^{38}\right] \mathrm{CRH},[\mathrm{D}-$ $\left.\mathrm{Phe}^{12}, \mathrm{Cys}(\operatorname{Pr})^{21}, \mathrm{Cys}(\mathrm{Et})^{38}\right] \mathrm{CRH}$ and $\left[\mathrm{D}-\mathrm{Phe}^{12}, \mathrm{Cys}(\mathrm{Pr})^{21}\right.$, $\left.\mathrm{Cys}(\operatorname{Pr})^{38}\right] \mathrm{CRH}$.

Both [D-Phe ${ }^{12}$, Cys $\left.(\mathrm{Et})^{21}\right] \mathrm{CRH}$ and $\left[\mathrm{D}-\mathrm{Phe}{ }^{12}, \mathrm{Cys}(\mathrm{Pr})^{38}\right]$ $\mathrm{CRH}$ present reduced affinity to the receptor compared to $\mathrm{CRH}$, which is approximately half that of the hormone. Notably, when these modifications are combined in the $\left[\mathrm{D}-\mathrm{Ph} \mathrm{P}^{12}, \mathrm{Cys}(\mathrm{Et})^{21}, \mathrm{Cys}(\mathrm{Pr})^{38}\right] \mathrm{CRH}$ analogue, the affinity appears to enhance significantly. However, this combination does not have the same impact on the activity of the molecule. [D-Phe ${ }^{12}$, Cys $\left.(\mathrm{Et})^{21}\right] \mathrm{CRH}$ is the only of the studied analogues that presents a higher than CRH activity $(110 \%$ that of the hormone) whereas [D-Phe $\left.e^{12}, \mathrm{Cys}(\mathrm{Pr})^{38}\right] \mathrm{CRH}$ shows reduced activity (60\% that of $\mathrm{CRH})$. The activity of $\left[\mathrm{D}-\mathrm{Phe}{ }^{12}, \mathrm{Cys}(\mathrm{Et})^{21}, \mathrm{Cys}(\mathrm{Pr})^{38}\right] \mathrm{CRH}$, although slightly higher than that of the latter monosubstituted analogue is considerably lower than that of the former one. This could mean that the negative effect of $\mathrm{Cys}(\mathrm{Pr})^{38}$ is more prominent than the positive one of $\mathrm{Cys}(\mathrm{Et})^{21}$. As for the affinity, no safe assumptions can be made until further NMR studies are performed on these molecules.

The results regarding $\left[\mathrm{D}-\mathrm{Phe}{ }^{12}, \mathrm{Cys}(\mathrm{Pr})^{21}, \mathrm{Cys}(\mathrm{Pr})^{38}\right]$ $\mathrm{CRH}$ indicate that double substitution with $\mathrm{Cys}(\mathrm{Pr})$ does not affect the affinity of the molecule to the receptor and decreases only slightly its activity. When the $\mathrm{Cys}(\mathrm{Pr})$ residue is applied at position 38 the $\mathrm{IC}_{50}$ value is negatively affected and the molecule shows a $40 \%$ decrease in activity compared to $\mathrm{CRH}$. The reversal of this image with the application of $\mathrm{Cys}(\operatorname{Pr})^{21}$ could be attributed to a positive effect of this moiety on the molecule but this assumption can be confirmed only by the study of the [D-Phe $\left.{ }^{12}, \mathrm{Cys}(\mathrm{Pr})^{21}\right] \mathrm{CRH}$ analogue that remains to be performed.

The analogue presenting the lowest $\mathrm{IC}_{50}$ value is $\left[\mathrm{D}-\mathrm{Phe}^{12}, \mathrm{Cys}(\mathrm{Pr})^{21}, \mathrm{Cys}(\mathrm{Et})^{38}\right] \mathrm{CRH}$, indicating a 5 -fold increased affinity to the receptor compared to the native hormone and also to the $\left[\mathrm{D}-\mathrm{Ph} e^{12}, \mathrm{Cys}(\mathrm{Pr})^{21}, \mathrm{Cys}(\mathrm{Pr})^{38}\right] \mathrm{CRH}$. Regarding the two $\mathrm{CRH}$ analogues it could be assumed that the difference in affinity is connected with the residue at position 38, where the $\mathrm{Cys}(\mathrm{Et})$ substitution appears to be more favorable compared to Cys $(\operatorname{Pr})$ substitution.

Considering all the aforementioned remarks, the conclusions are (i) regarding the introduction of Aib, position 15 is preferable to position 14 since it yielded analogues with higher affinity to the receptor; (ii) although the introduction of Aib modifies the secondary structure and can alter significantly the affinity to the receptor, the Aib containing analogues can still be characterised as partial agonists; (iii) affinity to the receptor and activity do not necessarily coincide and analogues that excel in the one may fall short to the other; (iv) simple or combined modifications with $\mathrm{Cys}(\mathrm{Et})$ or $\mathrm{Cys}(\mathrm{Pr})$ in position 21 or/and position $38 \mathrm{did}$ not hinder receptor recognition leading, in the most of the cases, to partial agonists with the exception of the analogue $\left[\mathrm{D}-\mathrm{Phe}{ }^{12}\right.$, Cys $\left.(\mathrm{Et})^{21}\right] \mathrm{CRH}$ which presents full agonistic activity.

\section{Acknowledgment}

State Scholarships Foundation (S.P.) is acknowledged for financial support.

\section{References}

[1] W. Vale, J. Spiess, C. Rivier, and J. Rivier, "Characterization of a 41-residue ovine hypothalamic peptide that stimulates secretion of corticotropin and $\beta$-endorphin," Science, vol. 213, no. 4514, pp. 1394-1397, 1981.

[2] W. Vale, C. Rivier, M. R. Brown et al., "Chemical and biological characterization of corticotropin releasing factor," Recent Progress in Hormone Research, vol. 39, pp. 245-270, 1983.

[3] F. A. Antoni, "Hypothalamic control of adrenocorticotropin secretion: advances since the discovery of 41-residue corticotropin-releasing factor," Endocrine Reviews, vol. 7, no. 4, pp. 351-378, 1986.

[4] D. N. Orth, "Corticotropin-releasing hormone in humans," Endocrine Reviews, vol. 13, no. 2, pp. 164-191, 1992.

[5] F. Holsboer, "The rationale for corticotropin-releasing hormone receptor (CRH-R) antagonists to treat depression and anxiety," Journal of Psychiatric Research, vol. 33, no. 3, pp. 181214, 1999.

[6] A. Erhardt, M. Ising, P. G. Unschuld et al., "Regulation of the hypothalamic-pituitary-adrenocortical system in patients with panic disorder," Neuropsychopharmacology, vol. 31, no. 11, pp. 2515-2522,2006. 
[7] D. G. Parkes, R. S. Weisinger, and C. N. May, "Cardiovascular actions of CRH and urocortin: an update," Peptides, vol. 22, no. 5, pp. 821-827, 2001.

[8] J. Raber, S. Chen, L. Mucke, and L. Feng, "Corticotropinreleasing factor and adrenocorticotrophic hormone as potential central mediators of OB effects," The Journal of Biological Chemistry, vol. 272, no. 24, pp. 15057-15060, 1997.

[9] P. J. Gilligan, D. W. Robertson, and R. Zaczek, "Corticotropin releasing factor (CRF) receptor modulators: progress and opportunities for new therapeutic agents," Journal of Medicinal Chemistry, vol. 43, no. 9, pp. 1641-1660, 2000.

[10] J. Vauhan, C. Donaldson, J. Bittencourt et al., "Urocortin, a mammalian neuropeptide related to fish urotensin I and to corticotropin-releasing factor," Nature, vol. 378, no. 6554, pp. 287-292, 1995.

[11] S. Y. Hsu and A. J. W. Hsueh, "Human stresscopin and stresscopin-related peptide are selective ligands for the type 2 corticotropin-releasing hormone receptor," Nature Medicine, vol. 7, no. 5, pp. 605-611, 2001.

[12] T. M. Reyes, K. Lewis, M. H. Perrin et al., "Urocortin II: a member of the corticotropin-releasing factor (CRF) neuropeptide family that is selectively bound by type $2 \mathrm{CRF}$ receptors," Proceedings of the National Academy of Sciences of the United States of America, vol. 98, no. 5, pp. 2843-2848, 2001.

[13] K. Lewis, C. Li, M. H. Perrin et al., "Identification of urocortin III, an additional member of the corticotropin-releasing factor (CRF) family with high affinity for the $\mathrm{CRF}_{2}$ receptor," Proceedings of the National Academy of Sciences of the United States of America, vol. 98, no. 13, pp. 7570-7575, 2001.

[14] D. T. Chalmers, T. W. Lovenberg, D. E. Grigoriadis, D. P. Behan, and E. B. De Souza, "Corticotrophin-releasing factor receptors: from molecular biology to drug design," Trends in Pharmacological Sciences, vol. 17, no. 4, pp. 166-172, 1996.

[15] W. A. Kostich, A. Chen, K. Sperle, and B. L. Largent, "Molecular identification and analysis of a novel human corticotropin-releasing factor (CRF) receptor: the $\operatorname{CRF}(2 \gamma)$ receptor," Molecular Endocrinology, vol. 12, no. 8, pp. 10771085, 1998.

[16] O. Valdenaire, T. Giller, V. Breu, J. Gottowik, and G. Kilpatrick, "A new functional isoform of the human $\mathrm{CRF}_{2}$ receptor for corticotropin- releasing factor," Biochimica et Biophysica Acta, vol. 1352, no. 2, pp. 129-132, 1997.

[17] B. E. DeSouza, W. T. Lovenberg, T. D. Chalmers, et al., "Heterogeneity of corticotropin releasing factor receptors: multiple targets for the treatment of CNS and inflammatory disorders," Annual Reports in Medicinal Chemistry, vol. 30, pp. 21-30, 1995.

[18] P. J. Lowry, R. J. Woods, and S. Baigent, "Corticotropin releasing factor and its binding protein," Pharmacology Biochemistry and Behavior, vol. 54, no. 1, pp. 305-308, 1996.

[19] R. Chen, K. A. Lewis, M. H. Perrin, and W. W. Vale, "Expression cloning of a human corticotropin-releasingfactor receptor," Proceedings of the National Academy of Sciences of the United States of America, vol. 90, no. 19, pp. 8967-8971, 1993.

[20] G. W. Smith, J.-M. Aubry, F. Dellu et al., "Corticotropin releasing factor receptor 1-deficient mice display decreased anxiety, impaired stress response, and aberrant neuroendocrine development," Neuron, vol. 20, no. 6, pp. 1093-1102, 1998.
[21] L. Facci, D. A. Stevens, M. Pangallo, D. Franceschini, S. D. Skaper, and P. J. L. M. Strijbos, "Corticotropin-releasing factor (CRF) and related peptides confer neuroprotection via type 1 CRF receptors," Neuropharmacology, vol. 45, no. 5, pp. 623636, 2003.

[22] S. C. Heinrichs and Y. Taché, "Therapeutic potential of CRF receptor antagonists: a gut-brain perspective," Expert Opinion on Investigational Drugs, vol. 10, no. 4, pp. 647-659, 2001.

[23] Z. Sarnyai, Y. Shaham, and S. C. Heinrichs, "The role of corticotropin-releasing factor in drug addiction," Pharmacological Reviews, vol. 53, no. 2, pp. 209-243, 2001.

[24] D. Richard, Q. Lin, and E. Timofeeva, "The corticotropinreleasing factor family of peptides and CRF receptors: their roles in the regulation of energy balance," European Journal of Pharmacology, vol. 440, no. 2-3, pp. 189-197, 2002.

[25] G. R. Valdez, "Development of $\mathrm{CRF}_{1}$ receptor antagonists as antidepressants and anxiolytics: progress to date," CNS Drugs, vol. 20, no. 11, pp. 887-896, 2006.

[26] P. A. Keller, L. Elfick, J. Garner, J. Morgan, and A. Mccluskey, "Corticotropin releasing hormone: therapeutic implications and medicinal chemistry developments," Bioorganic and Medicinal Chemistry, vol. 8, no. 6, pp. 1213-1223, 2000.

[27] N. Gibbs, R. B. Sessions, P. B. Williams, and C. E. Dempsey, "Helix bending in alamethicin: molecular dynamics simulations and amide hydrogen exchange in methanol," Biophysical Journal, vol. 72, no. 6, pp. 2490-2495, 1997.

[28] C. Toniolo, G. M. Bonora, V. Barone et al., "Conformation of pleionomers of $\alpha$-aminoisobutyric acid," Macromolecules, vol. 18 , no. 5, pp. 895-902, 1985.

[29] D. Theodoropoulus, "Synthesis of certain S-substituted Lcysteines," Acta Chemica Scandinavica, vol. 13, no. 383, p. 384, 1959.

[30] G. B. Fields and R. L. Noble, "Solid phase peptide synthesis utilizing 9-fluorenylmethoxycarbonyl amino acids," International Journal of Peptide and Protein Research, vol. 35, no. 3, pp. 161214, 1990.

[31] H. Rink, "Solid-phase synthesis of protected peptide fragments using a trialkoxy-diphenyl-methylester resin," Tetrahedron Letters, vol. 28, no. 33, pp. 3787-3790, 1987.

[32] K. Barlos, O. Chatzi, D. Gatos, and G. Stavropoulos, "2Chlorotrityl chloride resin: studies on anchoring of Fmocamino acids and peptide cleavage," International Journal of Peptide and Protein Research, vol. 37, no. 6, pp. 513-520, 1991.

[33] M. S. Bernatowicz, S. B. Daniels, and H. Köster, "A comparison of acid labile linkage agents for the synthesis of peptide Cterminal amides," Tetrahedron Letters, vol. 30, no. 35, pp. 4645-4648, 1989.

[34] W. König and R. Geiger, "A new method for synthesis of peptides: activation of the carboxyl group with dicyclohexylcarbodiimide using 1-hydroxybenzotriazoles as additives," Chemische Berichte, vol. 103, no. 3, pp. 788-798, 1970.

[35] D. Sarantakis, J. Teichman, E. L. Lien, and R. L. Fenichel, "A novel cyclic undecapeptide, WY-40,770, with prolonged growth hormone release inhibiting activity," Biochemical and Biophysical Research Communications, vol. 73, no. 2, pp. 336$342,1976$.

[36] R. Knorr, A. Trzeciak, W. Bannwarth, and D. Gillessen, "New coupling reagents in peptide chemistry," Tetrahedron Letters, vol. 30, no. 15, pp. 1927-1930, 1989.

[37] E. Kaiser, R. L. Colescott, C. D. Bossinger, and P. I. Cook, "Color test for detection of free terminal amino groups in the solid-phase synthesis of peptides," Analytical Biochemistry, vol. 34, no. 2, pp. 595-598, 1970. 
[38] T. Vojkovsky, "Detection of secondary amines on solid phase," Peptide Research, vol. 8, no. 4, pp. 236-237, 1995.

[39] G. A. Spyroulias, S. Papazacharias, G. Pairas, and P. Cordopatis, "Monitoring the structural consequences of Phe12 $\rightarrow$ D-Phe and Leu15 $\rightarrow$ Aib substitution in human/rat corticotropin releasing hormone: implications for design of CRH antagonists," European Journal of Biochemistry, vol. 269, no. 24, pp. 6009-6019, 2002.

[40] J. Pérodin, R. Bouley, E. Escher et al., "Angiotensin II analogues with sulphur-containing side-chains in position 5. A structure-activity relationship study," ArzneimittelForschung/Drug Research, vol. 50, no. 6, pp. 526-529, 2000. 


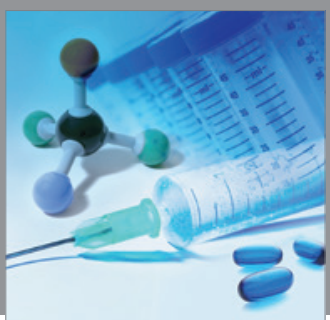

International Journal of

Medicinal Chemistry

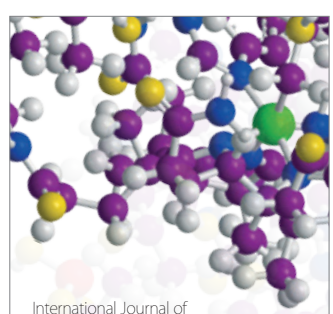

Carbohydrate Chemistry

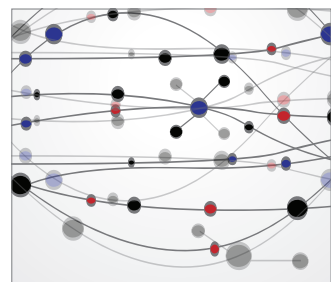

The Scientific World Journal
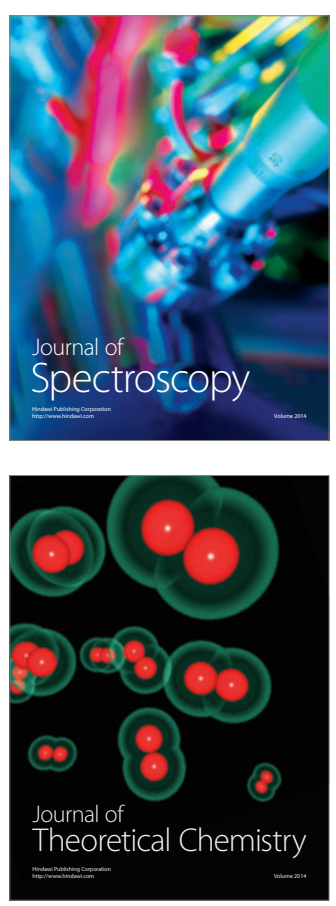
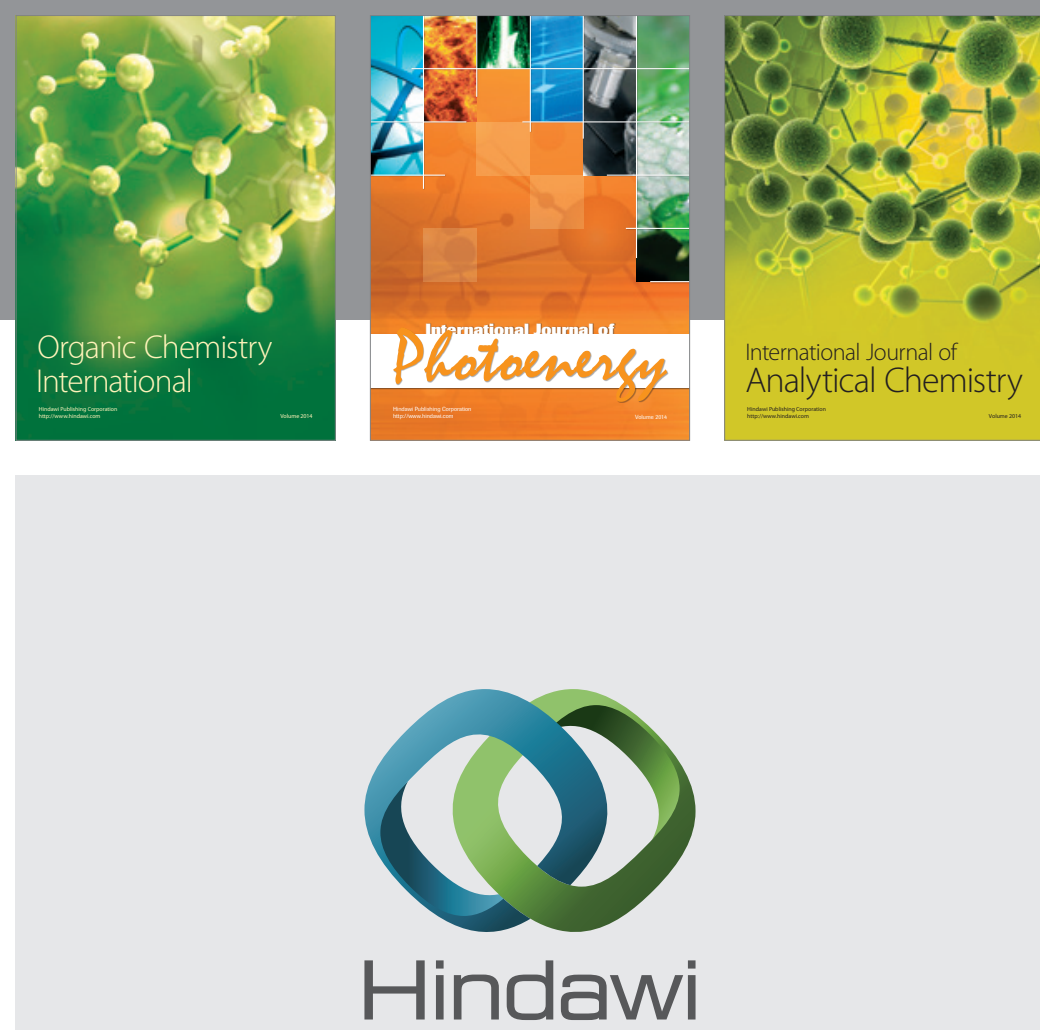

Submit your manuscripts at

http://www.hindawi.com
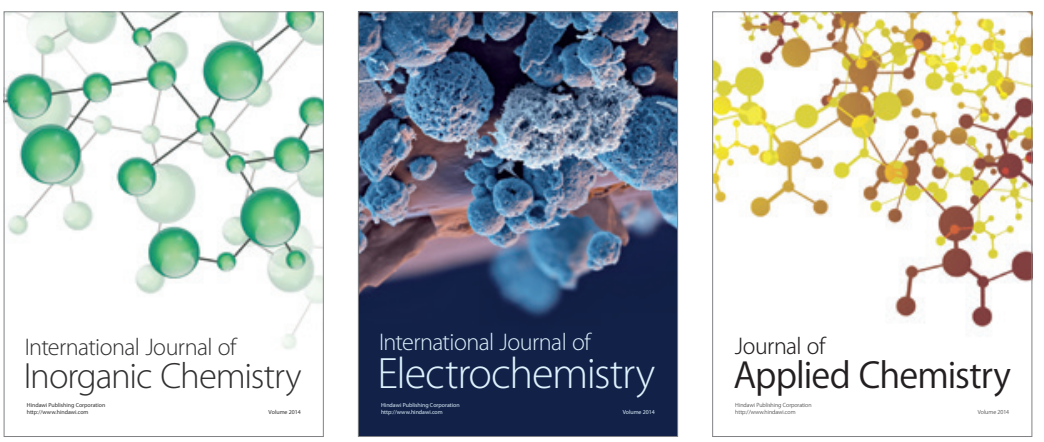

Journal of

Applied Chemistry
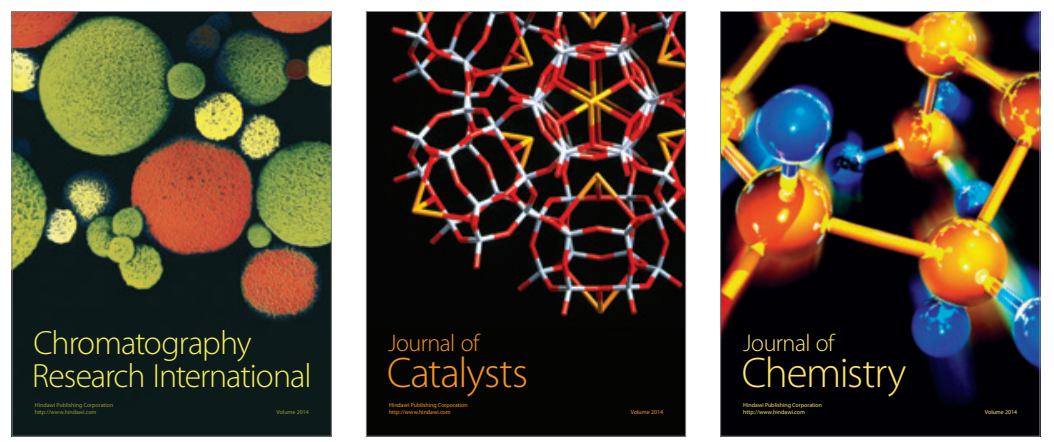
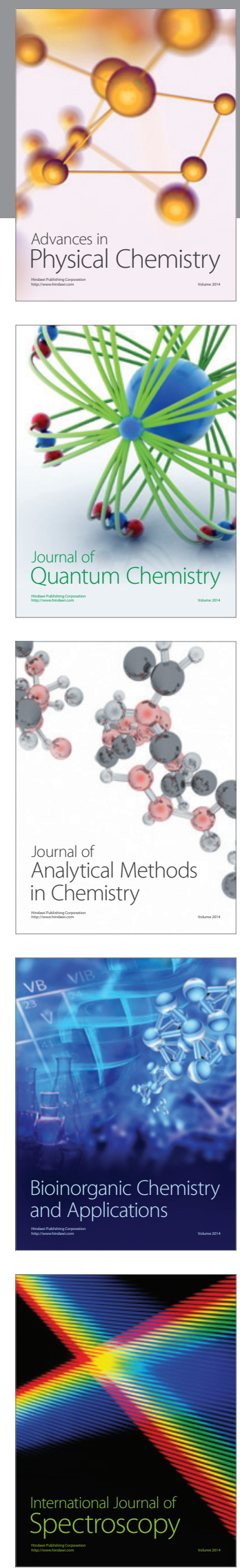